\section{Rooftop Solar PV Quality and Safety in Developing Countries - Key Issues and Potential Solutions}

To scale solar photovoltaic (PV) deployment in developing countries, the technology must be safe and reliable, meeting both customer and utility expectations. However, challenges exist in achieving these goals. Because PV systems are novel and complex, most consumers are unable to distinguish between low- and high-quality systems and may invest based on price alone. Suboptimal PV system performance and safety incidents can have downstream impacts on customer adoption and the solar industry because of unmet expectations and negative publicity. Rooftop solar system components vary in quality, and inadequate training for installers can lead to poor practices.

Inspection checklists, certification procedures, and standards are widely available (see Further Reading), but they may not be widely distributed or used in countries if they are not mandatory, if the workforce is not aware of them, or if installers lack the technical capacity to comply. Lessons learned and best practices from around the world can help developing countries address numerous potential solar PV deployment quality and safety challenges. This brief draws from the United States Agency for International Development (USAID) and the National Renewable Energy Laboratory's (NREL's) engagement in solar quality and safety in India [8] as well as NREL's multidecade research and experience.

\section{Concerns About Solar PV Safety and Quality}

Safety is important to avoid injury to people and damage to property. The quality of solar PV systems is important because it can affect the reliability and durability of the system.

However, it's not an 'either/or' proposition with safety and quality - the two are very much integrated. Low-quality systems may deliver less energy and have a lower overall life span. That alone is undesirable. But low-quality systems can also create safety risks for homeowners and businesses. They can reduce developer, investor, and consumer confidence in solar products. Quality and safety issues can slow market development and are likely key contributing factors in slowing rooftop PV installations - particularly, smallcapacity systems in developing countries.

These issues are most common among rooftop solar PV systems. With a lack of technical expertise, it is difficult for smaller developers and their customers to assess the quality of equipment and installation practices. Additionally, the small size and high volume of these projects make it challenging for regulators, distribution utilities, and lenders to keep track of and enforce standards and guidelines for equipment and installation practices.

\section{Common Solar PV Safety Issues}

Solar PV systems are often considered safer than other types of energy generators because they are silent and have no moving parts or flammable fuel. Still, safety is the imperative for both solar companies and consumers to avoid injury or property damage. The common hazards associated with installing PV systems include [10, 11]:
- Working at height - PV installers should practice good ladder and roof safety, ensure tools are managed safely, and take precautions to avoid sunburn, dehydration, and heatstroke during long stretches of exposure to hot, sunny, or dry conditions.

- Electrical safety-Electrocution is a hazard with any electrical system. Once plugged in, PV modules are energized when exposed to light, so circuits must be arranged to enable quick disconnects and rapid shutdowns. PV installers should have specialized training and personal protective equipment to work with energized circuits that cannot be turned off.

- Post-installation hazards-Once installed, operators and homeowners should learn about hazards that can evolve over time, such as ground faults, arc faults, loosened PV modules at risk of becoming windborne or falling from a roof, and conduit and wire damage that may cause fire.

National electrical codes and standards typically govern safety for installed electrical systems. Authorities adopt these kinds of safety standards for enforcement within their jurisdictions.

\section{Common Solar PV Quality Issues}

While most solar systems meet performance expectations, some solar PV safety and quality issues have been observed worldwide since the technology's early deployment in the 1980s [1]. Early on, PV system failures were dominated by $[2,6,7,9]$ :

\section{- Module and inverter component} failures-Component failures (e.g., cracked wires, connectors, and compromised solder bonds), often in the modules and inverters, were 
common in early deployment. However, with better PV component testing and standards, these failures are less common. Component standards, such as the International Electrotechnical Commission (IEC) 61730 for module safety and IEC 61215 for module design qualification (see Further Reading), include tests and are now a necessary requirement for many large system procurements.

- System downtime - Primarily caused by inverter failures and nuisance trips, system downtime was a recurrent problem in early systems and took longer to resolve than other early failures. Revised and new inverter standards, such as IEC 62109 for safety and 62093 for design qualification in natural environments (see Further Reading), have led to fewer instances of system downtime over the years. The process of updating standards to minimize downtime is a continual process as technology and needs evolve.

\section{Module Certification Is Required in the United States, but Performance Standards Are Still Lacking \\ In the United States, laws dictate that a system and its components must be safe, but performance standards are not strictly mandated. For example, the National Electric Code (NEC) requires that modules be listed, which requires certification to safety standard IEC 61730/ Underwriters' Laboratories (UL) 61730. In addition to module certification, the NEC and building codes also govern system wiring and grid connection, fire-resistance requirements, and mechanical loads. Only recently have organizations started to require performance standards, e.g., the American Cities Climate Challenge, where the suggested request for proposal requires IEC 61215/UL 61215 design qualification.}

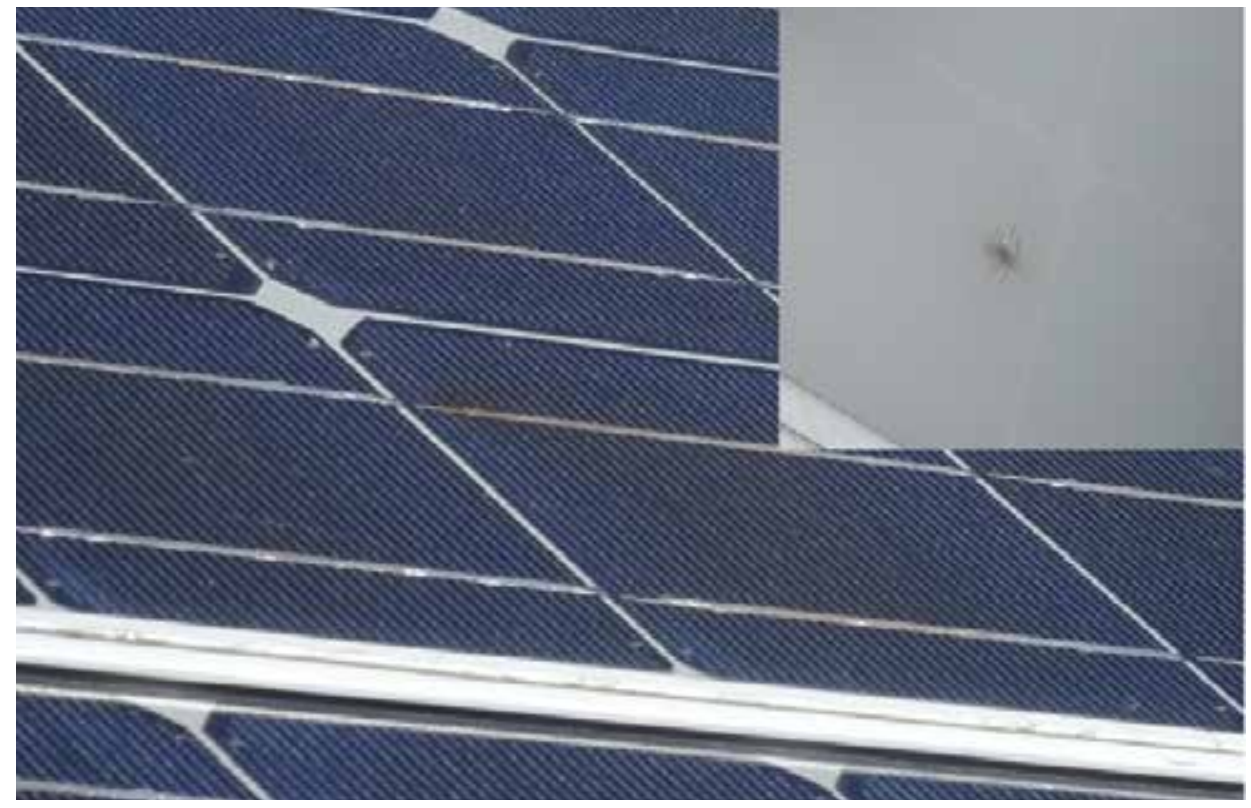

Figure 1. Solder bond failure leads to a hot spot visible (zoomed in top right) from the front and back. Photo by Dirk Jordan, NREL

More recently, solar PV systems, particularly rooftop installations, face different quality and safety challenges $[2,6,7,9]$ :

\section{- System design and installation} issues-Poor decisions in any aspect of system design and installation have the potential to weaken overall solar energy generation. With tax incentives commonly tied to physical system completion, developers may prioritize completion over quality and energy generation. This can lead to poorer system performance despite the gains made over the years in module and component reliability. Moreover, some developers have installed rooftop systems with significant shading (e.g., facing north in the Northern Hemisphere) or inappropriate flushmounted configurations in locations with extremely hot temperatures.

\section{- Low consumer awareness - It is} challenging for rooftop solar customers to distinguish between high- and low-quality systems. Homeowners often consider cost per watt and online customer reviews when choosing an installer because they lack information about system quality metrics. Even when a customer is technically savvy enough to identify a problem with their PV system, it may be difficult to obtain warranty benefits from component manufacturers and installers.

\section{- Module quality and inspection} challenges - Quality and safety issues affect installers as well. Smaller installers do not have the same capacity as larger businesses and cannot afford random-sample module testing, which could result in receiving some lowerquality modules. Issues with these shipped modules include cell cracks and other problems that are not always visible. If inspections are not carefully designed to match observed problems with inspector expertise and availability, inspectors may delay projects unnecessarily.

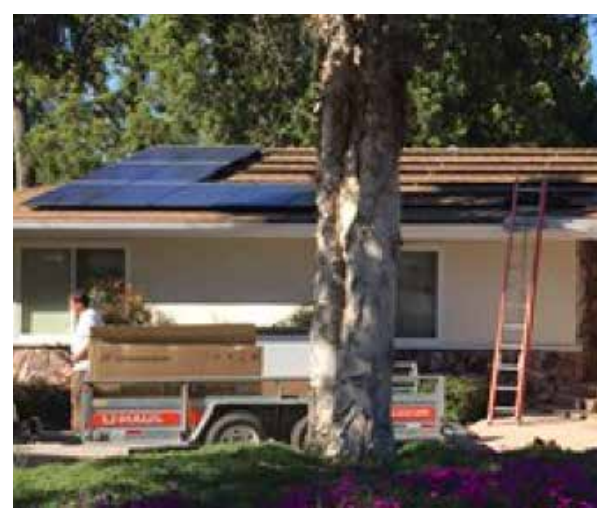

Figure 2. In California, shading of this PV system is the result of poor installation practices. Photo courtesy of homeowner. 


\begin{tabular}{|c|c|c|}
\hline Desired Characteristics & Observed Problems & Possible Solutions \\
\hline \multirow{3}{*}{$\begin{array}{l}\text { High-quality } \\
\text { components }\end{array}$} & Early-life component failure & $\begin{array}{l}\text { - Require IEC component certifications } \\
\text { - Publicize online to customers components that meet } \\
\text { requirements. }\end{array}$ \\
\hline & Counterfeit components & $\begin{array}{l}\text { - Perform inspections upon receipt of products. } \\
\text { - Implement import control and random testing of products } \\
\text { at market and make results available to consumers. } \\
\text { - Develop national certification labs, when possible. }\end{array}$ \\
\hline & $\begin{array}{l}\text { Installers buy poor-quality } \\
\text { components because they are most } \\
\text { readily available in the market. }\end{array}$ & $\begin{array}{l}\text { Provide channels of communication between installers } \\
\text { and distributors or manufacturers so those up the supply } \\
\text { chain know about problems and buyer preferences. }\end{array}$ \\
\hline $\begin{array}{l}\text { Competent installation } \\
\text { professionals }\end{array}$ & $\begin{array}{l}\text { Mistakes are made because of lack } \\
\text { of training or experience. }\end{array}$ & $\begin{array}{l}\text { - Make relevant training programs more accessible. } \\
\text { training or certification requirements. } \\
\text { - Require training or certification for installers to participate } \\
\text { in certain types of financing or incentive programs. } \\
\text { - Require system inspections by third parties or } \\
\text { government agencies. }\end{array}$ \\
\hline $\begin{array}{l}\text { Highest-quality } \\
\text { systems are } \\
\text { purchased }\end{array}$ & $\begin{array}{l}\text { Consumers purchase a low-quality } \\
\text { system because the initial cost is } \\
\text { the lowest. }\end{array}$ & $\begin{array}{l}\text { - Educate consumers that cost is not the only important } \\
\text { metric. } \\
\text { - Publicize from a trusted source, both online and in } \\
\text { stores, components and installers that demonstrate } \\
\text { exceptional quality - and those that have demonstrated } \\
\text { poor quality. } \\
\text { - Provide incentives to customers that participate in quality } \\
\text { programs. } \\
\text { - Make available a good warranty that installers may use } \\
\text { and customers may look for online. } \\
\text { - Make available financing options (e.g., system lease) } \\
\text { that provide incentives for both the customer and the } \\
\text { installer to consider quality. }\end{array}$ \\
\hline Confident buyers & $\begin{array}{l}\text { Consumers decide not to buy a } \\
\text { system because they have heard } \\
\text { about some problems. }\end{array}$ & $\begin{array}{l}\text { Establish a trusted third-party resource to continuously } \\
\text { update information online that allows consumers to } \\
\text { know they are selecting high-quality components and } \\
\text { installers. The information must be publicized so that } \\
\text { consumers are aware of the resource. } \\
\text { - Make available a good warranty that installers may use } \\
\text { and customers may look for online. } \\
\text { Make available financing options (e.g., system lease) } \\
\text { that provide incentives for both the customer and the } \\
\text { installer to consider quality. }\end{array}$ \\
\hline
\end{tabular}

Table 1. Desired Characteristics, Observed Problems, and Possible Solutions for PV Quality and Safety Issues [8]. 


\section{Improving Solar Quality and Safety-A Path Forward}

Over time, researchers and practitioners have developed best practices for overcoming common solar quality and safety issues - a process that is ongoing. Experience from NREL's PV reliability and system performance research, as well as other global research, points to a portfolio of possible solutions that target specific problems (Table 1). Up-todate and accessible communication to customers is critical to attract customers and meet their quality and safety needs. Also important are installer training and certification, use of certified components, inspections, incentives, warranties, and financing that encourages the purchase of high-quality systems.

NREL worked with international experts to develop a new framework aimed at improving solar quality and safety issues by addressing concerns throughout the stages of a PV system installation (see Text Box A).

Some countries, such as India, are taking novel approaches to address solar quality and safety concerns that have hampered rooftop solar deployment and market growth (see Text Box B). Like India, experts in other countries will need to understand how solar quality and safety issues manifest in terms of their specific type, frequency, and prevalence, then tailor solutions to fit their countries' unique situations.

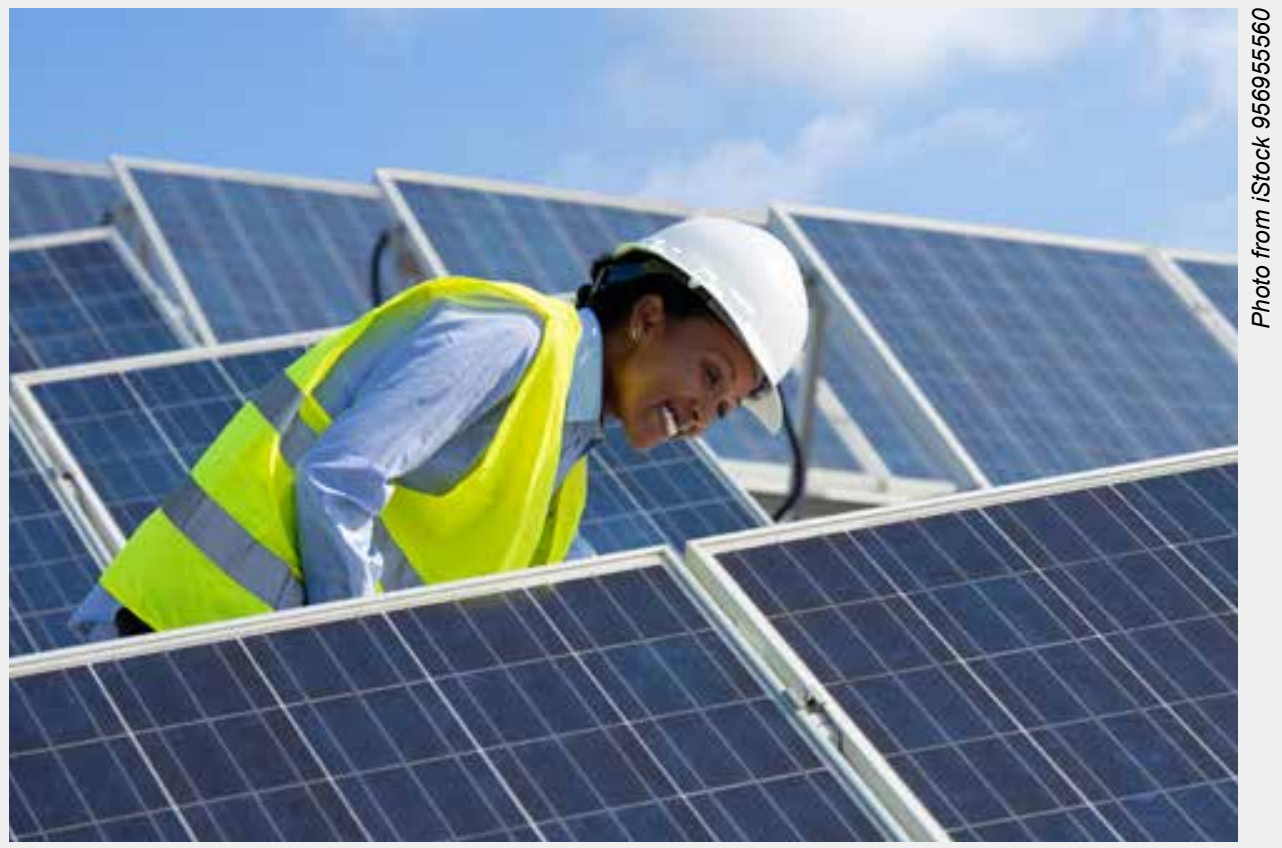

\section{Text Box A}

\section{International Electrotechnical Commission (IEC) System for Certification to Standards Relating to Equipment for Use in Renewable Energy Applications (IECRE)}

To improve PV system quality and provide solutions to the issues raised in this brief, teams of international experts (including NREL) developed the IECRE for PV system certification [4].

The team identified characteristics and actions associated with high-quality PV systems, coming to international consensus on these items, then updated or created more than 30 standards, technical specifications, and operational documents to reflect this content.

\section{Text Box B}

\section{Key Challenges in Rooftop Photovoltaic Solar (RTPV) Quality and Safety in India}

As the Government of India aims to reduce the cost and deploy $100 \mathrm{GW}$ of solar generation by 2022 , rooftop solar will play an integral role [3]. To identify key quality and safety challenges in deploying rooftop solar in India, NREL, USAID-India, and key partners facilitated a broad PV stakeholder engagement process, which included engineering, procurement, and construction companies, installers, developers, component manufacturers, authorities, financiers, and consultants.
The IECRE certifications and methods may be used as procurement requirements or as a way for vendors to demonstrate expertise in a competitive field. Operational documents that list the required standards for each IECRE certification are available free of charge [5]. IECRE operational documents relevant to $\mathrm{PV}$ system installation include:

- Choosing an installer (410-x)

- Commissioning (401)

- Checking system performance (402).

The process included collecting feedback from stakeholders via a survey, then conducting interviews and a workshop to identify the key challenges detailed in this brief. These challenges are primarily in the form of design quality, component quality, installation, and operation and maintenance quality issues. 


\section{Key Challenges in Rooftop Photovoltaic Solar (RTPV) Quality and Safety}

Goal: High-energy yield, low cost RTPV system
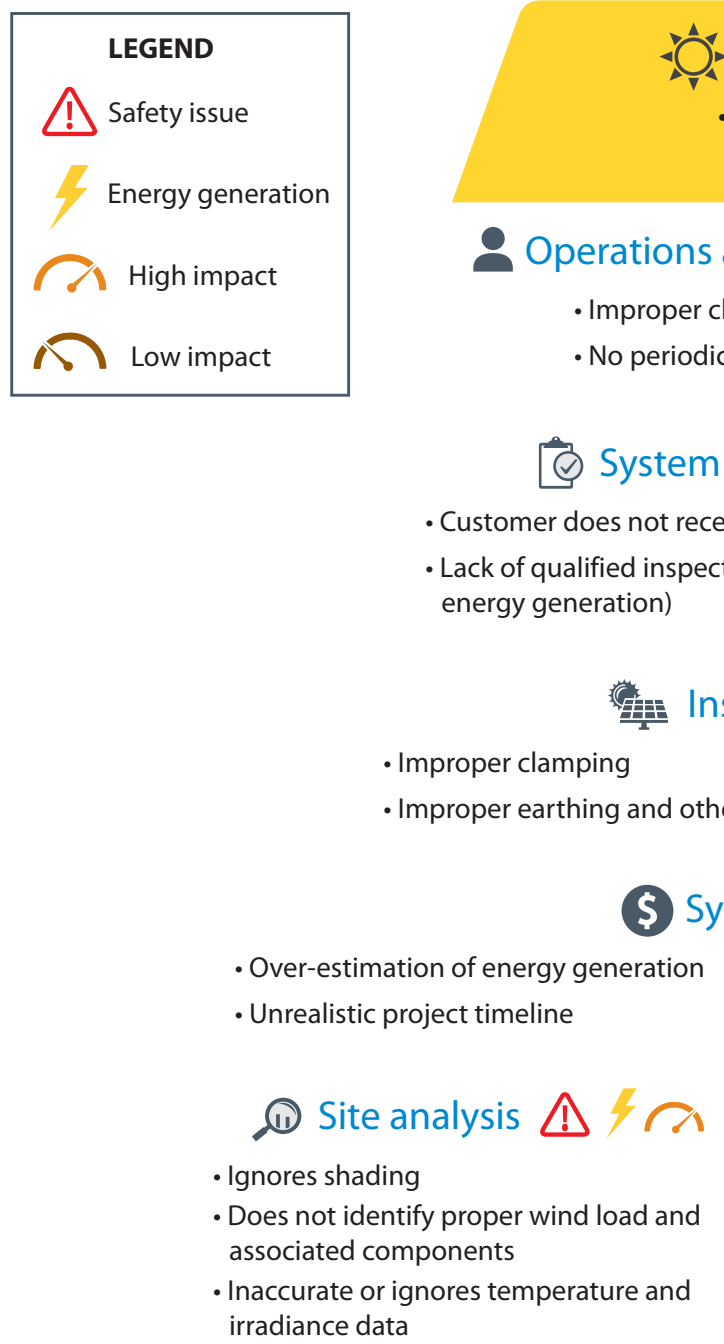

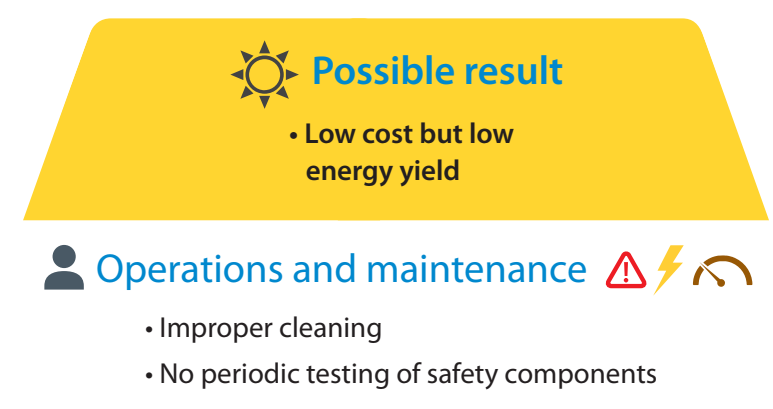

- Improper cleaning

\section{ystem commissioning 4 A}

- Customer does not receive warranties or engineering drawings

Lack of qualified inspection (e.g., earthing, adherence to designs,

$$
\text { Installation } \Delta / \text { ム }
$$

- Module handling damage

\section{Potential Solution: VRF}

In India, establishing a VRF is a key component of a prioritized approach to addressing these issues. A VRF helps measure the quality of systems and ensures compliance to established standards, tackling many of the quality and safety issues detailed previously. This requires a vendor-rating agency to provide scores and rankings to installers and other companies based on the quality of design, components, and installation practices-as well as the performance of the installed systems.
The VRF solution was informed by a process of literature review, survey feedback, stakeholder interviews, and a stakeholder workshop. In conducting a literature review of quality and safety issues associated with RTPV in India, NREL found the absence of independent supervision, inspection, and audit framework to be an issue. The subsequent stakeholder interviews and workshop solidified the need for a VRF, with many stakeholders agreeing that it is the appropriate next step in India. A pilot designed to test and evaluate the framework, implemented with 10 engineering, procurement, and construction companies at more than 50 commercial and residential sites in the state of Gujarat, helped inform a scaled country-level approach. In partnership with USAID, and after multiple stakeholder engagement sessions, the Confederation of Indian Industry-Godrej Green Business Center launched the VRF process in 2021. In addition to identifying assessor agencies, the Confederation is working on a website and mobile application to implement the VRF. Vendors demonstrated interest in participating in the process.

For more information, see [8]. 


\section{References}

[1] Jordan D. C., B. Marion, C. Deline, T. Barnes, and M. Bolinger. PV Field Reliability Status-Analysis of 100,000 Solar Systems. Prog Photovolt Res Appl. 2020; 28:739-754. https://doi. org/10.1002/pip.3262

[2] Duke, Richard D., Arne Jacobson, and Daniel M. Kammen. 2002. Photovoltaic Module Quality in the Kenyan Solar Home Systems Market. Energy Policy 30 (6): 477-99. https://doi.org/10.1016/S03014215(01)00108-2.

[3] Government of India. 2015. India Surging Ahead in the Field of Green Energy-100-GW Solar ScaleUp Plan. https://pib.gov.in/newsite/PrintRelease. aspx?relid=122566.

[4] International Electrotechnical Commission (IEC). IEC System for Certification to Standards Relating to Equipment for Use in Renewable Energy Applications (IECRE). www.iecre.org.

[5] International Electrotechnical Commission (IEC). Rules, Operational Documents, and Guides. https://www.iecre.org/documents/refdocs/refdocs entry.htm.

[6] International Renewable Energy Agency (IRENA). 2017. Boosting Solar PV Markets: The Role of Quality Infrastructure. https://www.irena. org/publications/2017/Sep/Boosting-solar-PVmarkets-The-role-of-quality-infrastructure.

[7] Jacobson, Arne, and Daniel M. Kammen. 2007. Engineering, Institutions, and the Public Interest: Evaluating Product Quality in the Kenyan Solar Photovoltaics Industry. Energy Policy 35 (5): 2960 68. https://doi.org/10.1016/j.enpol.2006.10.024.

[8] Karandikar, A., I. Repins, A. Aznar, C. GokhaleWelch, R. Khanna, R., and D. Anand. Distributed Solar Quality and Safety in India: Key Challenges and Potential Solutions. July 2020. NREL, Nexus Energytec Pvt Ltd, Tetrat Tech. https://www.nrel. gov/docs/fy20osti/74833.pdf.
[9] Mills, Evan, Jennifer L. Tracy, Peter Alstone, Arne Jacobson, and Patrick Avato. 2014. Low-Cost Led Flashlights and Market Spoiling in Kenya's OffGrid Lighting Market. Energy Efficiency 8 (April). https://doi.org/10.1007/s12053-014-9294-2.

[10] National Renewable Energy Laboratory, Sandia National Laboratory, SunSpec Alliance, and the SunShot National Laboratory Multiyear Partnership (SuNLaMP) PV O\&M Best Practices Working Group. 2018. Best Practices for Operation and Maintenance of Photovoltaic and Energy Storage Systems; 3rd Edition. Golden, CO: National Renewable Energy Laboratory. NREL/ TP-7A40-73822. https://www.nrel.gov/docs/ fy19osti/73822.pdf.

[11] Solar Access to Public Capital (SAPC) Working Group. 2015. Best Practices in PV System Installation; Version 1.0. Golden, CO: National Renewable Energy Laboratory. NREL/ SR-6A20-63234. https://www.nrel.gov/docs/ fy15osti/63234.pdf.

\section{Further Reading}

NREL has worked in industry-wide collaborations to develop best practices guides for several topics related to PV safety and quality:

- Best Practices in Commercial and Industrial (C\&I) Solar Photovoltaic System Installation covers a best-practices guide for commercial and industrial PV installations and is available here: https://www.nrel.gov/docs/fy16osti/65286.pdf.

- Best Practices Handbook for the Collection and Use of Solar Resource Data for Solar Energy Applications addresses key aspects of solar resource characterization and is available here: https://www.nrel.gov/docs/fy15osti/63112.pdf.

- Best Practices for Operation and Maintenance of Photovoltaic and Energy Storage Systems; 3rd Edition is a guide that covers planning and delivering effective O\&M best practices. It is available at: https://www.nrel.gov/docs/fy19osti/73822.pdf.
- Best Practices in PV System Installation covers several aspects of installation, including requirements for personnel training, company experience and solvency, shading analysis, shading packages, and system production estimates. Requirements are organized into a short checklist in each section of the guide. Access it here: https://www.nrel.gov/ docs/fy15osti/63234.pdf

- International Best Practices for Implementing and Designing Renewable Portfolio Standard (RPS) Policies is a guide that covers the development of renewable portfolio standards and is available here: https://www.nrel.gov/docs/ fy19osti/72798.pdf.

Examples of inspection checklists, certifications, and industry standards:

- International Electrotechnical Commission (IEC) 61215 for module design qualification https:// webstore.iec.ch/publication/61345.

- International Electrotechnical Commission (IEC) 61730 for module safety https://webstore.iec.ch/ publication/25674.

- International Electrotechnical Commission (IEC) System for Certification to Standards Relating to Equipment for Use in Renewable Energy Applications (IECRE) https://www.iecre.org/

- International Electrotechnical Commission (IEC) 62109 for inverter safety https://webstore.iec.ch/ publication/6470

- International Electrotechnical Commission (IEC) 62093 for design in natural environments https:// webstore.iec.ch/publication/6453

- Model Inspection Checklist for Rooftop PV Systems. http://www.irecusa.org/wp-content uploads/2013/09/Model-Inspection-Checklist.pdf.

- Solar Inspection Checklist. Institute for Building Technology Safety (blog). https://www.ibts.org/ solar-inspection-checklist.
This work was authored, in part, by the National Renewable Energy Laboratory (NREL), operated by Alliance for Sustainable Energy, LLC, for the U.S. Department of Energy (DOE) under Contract No. DE-AC36-08GO28308. Funding provided by the United States Agency for International Development (USAID) under Contract No. IAG-17-2050. not necessarily represent the views of the DOE or the U.S. Government, or any agency thereof, including USAID. The views expressed in this report do

The Distributed Photovoltaics Toolkit provides resources to support developing countries in addressing barriers to safe, effective, and accelerated deployment of distributed solar power. Greening the Grid is supported by the U.S. Agency for International Development. Reach out to greeningthegrid@nrel.gov for more information.

The USAID-NREL Partnership addresses critical challenges to scaling up advanced energy systems through global tools and technical assistance, including the Renewable Energy Data Explorer, Greening the Grid, the International Jobs and Economic Development Impacts tool, and the Resilient Energy Platform. More information can be found at: www.nrel.gov/usaid-partnership.
Resilient Energy Platform 